\title{
Otherness and the problem of evil: How does that which is other become evil?
}

\author{
Calvin O. Schrag
}

Received: 3 November 2005 / Accepted: 23 February 2006 /

Published online: 6 September 2006

(C) Springer Science+Business Media B. V. 2006

\begin{abstract}
In seeking to answer the question "How does that which is other become evil?" the author provides a discussion of four entwined aspects of the issue at stake: (1) difficulty in achieving clarity on the grammar of evil; (2) genocide as a striking illustration of otherness becoming evil; (3) the challenge of postnationalism as a resource for dealing with otherness in the socio-political arena; and (4) the ethicoreligious dimension as it relates to the wider problem of evil.
\end{abstract}

Keywords Genocide · Theodicy · Postnationalism · Alienation · Dialogue • Communication · Friendship · Love $\cdot$ The gift · Rhetoric $\cdot$ Messianicity · Radical evil

The topic for discussion today is clearly not of recent times. It has, however, been very much in the news of late, both in the classrooms and seminars of academe and in the political and religious print of the public press. The topic is "The Problem of Evil". We all know that the problem of evil is a very big problem that has been with us for some time. It is a problem that bristles with semantic, psychological, political, ethical, religious, and metaphysical quandaries. Yet, in our variegated disciplines, professions, and walks of life we are called upon to address the problem. And to address the problem of evil is to endeavor to understand it, to comprehend what is meant by evil, and in some manner to explain its source or origin. But addressing the problem of evil also requires that we solicit resources to eradicate evil - abolish, annihilate, root it out - or at least mitigate it. But what if perchance one butts up against an impossibility in both of these requirements - an impossibility of comprehending evil and an impossibility of eradicating it? How then would it stand with such an impossibility? How would the impossible itself impact upon our thought, our discourse, and our action?

To address this formidable issue, I have chosen as the title for my remarks, "Otherness and the Problem of Evil". I will attempt to consolidate my reflections on certain aspects of the matter at stake by: (1) seeking some clarity on the grammar

C. O. Schrag $(\bowtie)$

Department of philosophy, Purdue University, West Lafayette, IN 47907, USA

e-mail: cschrag@purdue.edu 
of evil; (2) proceeding to a brief discussion of genocide as a striking illustration of "otherness" becoming evil; (3) moving then to the challenge of postnationalism as a socio-political resource for abridging the evils of genocide; and (4) concluding with some ethico-religious reflections on the topic.

\section{The grammar of evil}

The grammar of evil, it soon becomes evident, is not all that easy to sort out. A common recommendation for achieving clarity about the meaning of a word or concept is to consult a reliable dictionary. Surely Webster's International Dictionary is of such a kind. However, even it does not leave us with a straightforward answer to the question "What is evil?" Evil, we are told, is that which is not morally good; wicked; sinful; offensive; painful; foul; uncomfortable; disagreeable; unpleasant; wrathful; malignant; causing or tending to cause harm; calamity; disaster; misfortune - and I suspect all of the above in a variety of combinations.

To be sure, listing the manifold indicators of evil may do for starters, getting the conversation going, but one needs to proceed with an effort to somehow take up the slack in this somewhat bewildering polysemy of lexical signifiers. And of course the taking up of slack in the manifold senses of concepts and phrases is something that we as philosophers are supposed to do. And indeed the new Cambridge Dictionary of Philosophy is helpful in this regard by marking out a distinction between "natural evils" and "moral evils". Natural evils have to do with disruptive forces in nature which have the capability of raising havoc within even the realm of inanimate nature. Earthquakes, volcanoes, hurricanes, tornadoes, and floods are the most commonly referenced illustrations of this sort of natural evil. Indeed, during the early modern period the Lisbon earthquake of 1775 was singled out as the paradigmatic illustration of natural evil. But natural evils also encompass forms of non-human animate or living substances. Poisonous snakes, sharks, ferocious beasts, and even bed bugs are sometimes used as examples. This would situate the occurrence of evil prior to the emergence of the human species itself, in "the land before time", where tyrannosaurus rex may well have been judged to be evil by his victims - or in the current evolutionary stage in which the gazelle is likely inclined to view the lion as the archetype of evil. But there is another form of evil-moral evil, which is the result of malignant acts performed by human beings who apparently are able to do otherwise. During the twentieth century the Holocaust quickly became the paradigmatic instance of moral evil.

Truth to tell, the widespread occurrence of so called natural and moral evil quickly became a pesky problem for any metaphysics of theism with its proclamation of a deity who is at once omnipotent and omnibenevolent. This problem, generally defined as the problem of theodicy, sought for a justification of the occurrence of evil in conjunct with the belief in the existence of a deity that is at once all good and all powerful. Within such a theistic framework it would appear that to account for the existence of evil one would need to qualify either God's omnipotence or his omnibenevolence. Various proposals have been offered to answer this perplexing problem. It is not in the purview of my current project to review and critically evaluate these different proposals. This is a very big problem for any metaphysics of theism, and I prefer not to enter the fray at this juncture-only to suggest that there might be some merit in experimenting with a possible dissolution of the problem itself by deconstructing the metaphysical/cosmological construct of God as a cosmic architect and overlord, 
endowed with superhuman qualities of virtue and will. But the effort to dissolve this particular problem is not part of my agendum today. I have much smaller fish to fry relating to the problem of evil.

My question is: "How does that which is other become evil?" In pursuing this question I am restricting myself to what generally flies under the flag of "moral evil". For starters, what is needed is a preliminary clarification of certain operative terms in the discourse on otherness as it relates to the upsurge of evil. That which is other is somehow separate or different from a given object, person, event, or state of affairs. Separateness and difference, at least on one level, can be understood to be roughly equivalent. Now it is the lot of our terrestrial finitude, our condition as finite creatures, to be separate from other entities in the world (such as external objects and other selves), and within a theological perspective (at least within some theological perspectives) to be separate from God-and particularly so if God is understood to be infinite, uncreated, and unconditioned in contrast to our created and conditioned finite existence. But the otherness of finitude as separateness and difference is not-at least not yet-alienation or estrangement. Estrangement as a coefficient of otherness, otherness under the conditions of estrangement, the other as stranger or alien, provides the mark of the separateness of finitude somehow gone wrong.

\section{The evil of genocide}

Now in pursuing the meaning of otherness as it slides into an intensification of alienation or estrangement one encounters a more foreboding and menacing posture of otherness. This is otherness as the intrusion of evil-and in some cases evil understood as unmitigated and rotten to the core, inviting aggressive measures for its removal. When this otherness as unmitigated evil defines an alien group, the stage is set for the horrors of genocide. To be sure, genocide, it might be said, is only one instance or expression of evil, but it should not be all that difficult to achieve agreement that it is one of the more salient expressions of evil in the history of humankind and reached a frightening level during the recent century.

The mindset that occasions genocide is rooted in the belief that the "other group" constitutes such a threat to one's personal, social, and national interests that it needs to be dealt with in a decisive and bold manner. The other is deemed to be intrinsically repugnant and unassimilable, not only to be kept at a distance as an outcast group of untouchables but veritably to be annihilated. It is precisely such a demonization of the other that opens the floodgates to genocide, a perspective on the otherness of the other that requires that the other be exterminated like a virus infecting an alien corporate body. The perpetrators of genocide are bent upon the systematic and unrelenting persecution of a group of persons simply because they are members of that group, including men, women, and children. The group is "the others" who are to be exterminated indiscriminately. However, the twisted logic of genocide prescribes not only the annihilation of the other but in truth the annihilation of all memory of $\mathrm{him} / \mathrm{her} / \mathrm{them}$. This involves not only silencing the witnesses of the annihilated and the narratives by the witnesses, but also all narratives about the witnesses, auguring in the direction of a veritable erasing of all traces of those who have been victimized.

Plainly enough, the negation of the other as other, projecting a veritable deletion of the other from the memory bank of history, reaches its most intense expression in the indiscriminate and merciless murder of genocide. Subject to a mania of purification, 
the perpetrators of genocide seek to safeguard the purity of their form of life by excising the polluted way of life of the other. Professor Bruce Wilshire captures this purification mania that underwrites much of the motivation of genocide when he reports: "All members of the alien group must be killed or incapacitated because each carries the germ of the alien world-experience: each threatens to poison and undermine the only world in which the home group has learned to live" (Wilshire, 2005). The other as unmitigated evil is seen as a germ that threatens to infect one's lifeworld and needs to be uprooted and all traces of the existence of the same destroyed. The other as individual or group - and for the perpetrator of genocide there is no distinction between the two-is to be ferreted out, isolated, and annihilated so as to ensure the purity and safety of those who feel threatened. There are, of course, the classic cases of genocide - the Nazi perpetration of horrors that culminated in the Holocaust; the systemic maneuvers to exterminate pockets of native American Indians; the policy of the Serbs to eradicate the Muslims; the designs of Pol Pot and the killing fields of Cambodia. But there are other examples of genocide that have received less attention but equally illustrate a mindset that the members of an alien group are somehow irremediably evil and need to be extirpated.

Now in confronting this expression of evil in its most radical form of genocide and its modulated varieties one needs to proceed with a requisite humility and acknowledgment of irremovable limits to human understanding. Indeed evil in its most radical form remains on the edge of human comprehensibility. Kant never quite got to this in his somewhat sanitized version of "radical evil", which in the end was not all that radical because he kept evil within the bounds of a "propensity to evil" resident in an innately good will. Jürgen Habermas gets closer to what is at issue in talk about "radical evil" when he prefaces his discussion of Auschwitz as "reflection on the incomprehensible". But reflect we must, and we need to do so with the lights and resources that we possess; and this involves thought experiments on how best to deal with this virulent form of evil that has become a part of our history. How can we keep otherness form sliding into a signifier of a radical evil that impedes our very powers of comprehension?

Let us begin with a more general observation. Any achievement of understanding and communicating with those who do not share our beliefs and practices is made possible by the gift of language, bequeathed to us mortals as homo loquens and homo narrans, speaking and narrating animals, who constitute ourselves in our discourse and our narratives as we make our way about in the world. As we live amongst the differences that punctuate the tensions between our lifeworld and the lifeworld of the other, it is the resource of language, dialogue, and communication that holds out hope for a possible convergence amidst ethnic, racial, political, and religious differences. And here we do have something important to learn from our Greek predecessors and particularly from their contributions to the positive role of rhetoric. It is of course Aristotle who quickly comes to mind with his notion of political-deliberative rhetoric, which, unlike forensics as a formal technique for winning points in a staged debate, is oriented toward deliberation and action designed to enhance the good for the wider polis.

The difficult task, however, is addressing the specific relevance and implications of the resources and limitations of our communicative endeavors in dealing with genocide as an intensification of moral evil. And even more specifically, what modifications in our domestic and international affairs are required to provide a kind of sheet anchor against the demonization of the other as "evil empire", "the Great Satan", or the "axis of evil" ? How can such a demonization of the other, which stands on the brink of the 
inhumanity of genocide, so visible both in our distant and recent past, be avoided? How can a transversal understanding and communication that strives to learn from differences as it works out policies of cooperation, respecting the integrity of otherness on matters of culturally based beliefs and practices, be achieved? In pursuing these timely and difficult questions/issues it may behoove us to do some thoughtexperimenting with alternative forms of socio-political organization. And such is part of the thought experiment that I wish to pursue-or begin to pursue - in my brief observations today.

\section{The challenge of postnationalism}

Might it be that the modern nation-state ontology which has been with us since the historic Treaty of Westphalia and which has conditioned us all to find our corporate identities in nation-making characteristics of common ethnic origins, language, culture, religion, and forms of government, has outworn its usefulness for the present age? The international configuration of nation-states, dividing socio-political collective associations into homogenous enclaves of common origins and shared history has fostered an exclusionary cultural mindset which at times can be fueled to incite various forms of genocide. The inhabitants of the various nation-states view their identity as somehow constituted by their allegiances to a socio-political way of life that is marked off from the lifeworld of other nation-states. When this national identity becomes intensified and rigid, the space that marks off national identities can become a breeding ground for the evils of genocide.

In more recent times there has been considerable discussion on the possible demise of the nation-state as a model for international politics. Samuel Huntington, for example, in his book, The Clash of Civilizations and the Remaking of World Order, defines the contemporary international scene as one in which conflicts of nation-states are being replaced by what he has named "the clash of civilizations" (Huntington, 1996). To be sure, the meaning of "civilization" may be as perplexing as is the meaning of "nationalism". And it soon becomes evident that Huntington's neat classification of nine contemporary civilizations is not without its arbitrariness. But be that as it may, his focus on the associated complexes of civilizations as cultural units as distinct from nation-states has direct relevance for any project of overcoming nation-state identities, inviting a shift away from "inter-national" to "post-national" politics.

Clearly, the path to such a postnational politics is not without its obstacles, requiring both a measure of philosophical imagination and realistic political analysis. And it is precisely such a paradigm shift that Jürgen Habermas proposes in his recent quite remarkable work, The Postnational Constellation (Habermas, 2001). Now the consequences of such a move in the direction of postnational identity and postnational political configurations would if not totally eradicate a nation-state based identity at least provide a mitigation of such. The other would no longer be deemed evil because of alien nation-making characteristics, such as geographical boundaries, common language, similarity of ethnic origins, and associated cultural practices.

Yet, profound as the move to a postnational constellation of the political might be, curtailing the motives of a nation-state based genocide, the threat of the evil of genocide is not as such displaced. Even in a postnational world one would have to deal with clashes of civilizations or cultures which themselves could ignite the fires of class hatred in which the other as other is demonized as the evil one. So more radical 
measures are required, and here both our philosophical and religious resources approach a kind of ultimate challenge. This challenge provides us with a possible opening to a transpolitical resolution to our problem of evil, beyond the economy of politically legislated distributive justice, auguring in the direction of a veritable surmounting of the friend/ enemy dichotomy with its intermittent invitations to a demonization of the other . Even if the clash of national identities and ideologies were to be overcome, the clash between friends and alleged enemies would remain in force. The enemy becomes the demonized other. It is thus that an extension of our thought experiment is required, inviting reflection on a possible move to an ethico-religious content and measure which might in some way inform our socio-political aspirations, seeking to overcome the nation-state ontology with the help of a dismantling of the friend/enemy dichotomy.

\section{Friends and enemies}

We are aided in this extension of our thought experiment, seeking a more radical resolution to the demonization of the other, by Jacques Derrida's ruminations on a Politics of Friendship and Søren Kierkegaard's unparalleled classic treatise Works of Love. Derrida expands the reach of friendship beyond the confines that have traditionally Søren been assigned to it. He does this by developing an internal connection between friendship and the gift. In the traditional literature on the topic, friendship is understood to function within a restricted economy of exchange relations. To establish a friendship is to expect something in return. Within such an economy one cannot be a friend with everyone. In developing his notion of friendship Aristotle remained within such an economy. For Aristotle friendship requires an interaction and exchange with equals, borne by relations of symmetry and reciprocity. You desire to find something in the comportment of your friend that will enhance your own self-realization. Admittedly, such a take on friendship can well contribute to a postnational democracy based on a distributive justice informed by equality and reciprocity. And indeed such is necessary and clearly desirable in any politics of friendship; but the peculiar and decisive trait of the more radical politics of friendship recommended by Derrida is a self transcendence that proceeds beyond itself as a politically informed constellation of justice that simply assigns to each the requirement of returning the same.

This procession beyond politically informed constellations of justice as equality and reciprocity, beyond the limited notion of friendship which keeps the dichotomy of friend verses enemy intact, is a move to the notion of the gift, genuinely understood as a thinking and a giving without expectation of return, transcending all economies of exchange relations, approaching its crest and culmination in the gift of love. The aneconomic gift of love at once transforms the restricted notion of friendship into a universal fraternity and sorority and sets the condition for the requirement to love even one's enemies. We are told, writes Derrida: "One is worthy of the eternal father only by loving one's enemy as one's neighbor or as oneself." Plainly enough, the gift of love thusly construed, transcends all economies of distribution and allotment, requiring that we "think the dissymmetry of a gift without exchange, therefore an infinite one-infinitely disproportionate, in any case, however modest it may be, from the vantage point of terrestrial finitude."(Derrida, 1997).

At this juncture we are straightway reminded of Kierkegaard's Works of Love (which may well have informed Derrida's ruminations on friendship). In this masterful work Kierkegaard undertakes a sustained hermeneutic on the Biblical commandment 
"Thou shalt love thy neighbor as thyself". Kierkegaard clearly recognizes that the enemy is also one's neighbor, and that the quality of love at issue extends beyond the friend/enemy dichotomy. My enemy also is an/other, a neighbor, someone who is "near-by" either in proximate or distant space, and whose presence solicits my love as much as does my friend. "Therefore the one who truly loves the neighbor loves also his enemy. The distinction friend or enemy is difference in the object of love, but love for the neighbor has the object that is without difference. The neighbor is the utterly unrecognizable dissimilarity between persons or is the eternal equality before God - the enemy, too, has this equality" (Kierkegaard, 1995, pp. 67-68). This love of the enemy as one's neighbor, Kierkegaard continues, is a love "without requirement of any reward... It has no reward, not even that of being loved." (pp. 130-131). It is readily apparent that Kierekgaard's take on love of neighbor, extending to the enemy, unconditional without expectation of a reward, is very much Derrida's "dissymmetry of a gift without exchange ... infinitely disproportionate from the vantage point of terrestrial finitude".

Truth to tell, in Kierkegaard's and Derrida's reflections on the gift of love, as infinite and unconditional, we are veritably placed in a region robustly transcendent to the frailities and fractures of the economy of our earth bound existence. And this, as Derrida is quick to point out, renders the performance of the gift an impossibility. On this point Kierkegaard also appears to be in accord with Derrida. Given Kierkegaard's profound sensitivities to the ambiguities of human motivation which inveigh against the purity of a self-sacrifice that sets no requirement of any reward, the gift of unconditional love, erasing the distinction between friend and enemy, remains an impossibility due to the foibles of the human condition. So it would appear that the resolution of the problem of the evil of genocide, with its demonization of the other as enemy, remains an impossibility within a Derridean politics of friendship, which as Derrida emphasizes is always not yet here, situated within the time of promise, projected into the future. Such also would seem to be the case in Kierkegaard's explication of agape , an unconditional love that underwrites the impossible task to love even one's enemy. But situating the resolution to the problem of evil as an "impossibility" within an aneconomic space of the future as the time of promise does not in any way erase the power of the possible. It is through the impossible, understood at once as s quasi-transcendental condition and an ethico-religious existential imperative, that we inform and vitalize that which is possible.

Plainly enough, the impossibility that is at issue here is of a quite distinctive sort. It is not to be confused with an ideal as a regulative principle that guides the enablement of distributive justice within the political economy of civil society - although clearly it does not sever its tie with the call for justice. The enablement of justice with its ideals in a struggle for human rights and fairness in human relations retains its obligatory force. Through the ingression of the ideals of justice we order our everyday lives and our political engagements, and all this advances the move toward a transcendence of national identities. But here we are still working with a limited notion of transcendence, a kind of transcendence-within-immanence-a transcendence within the relations of distribution and exchange among administrative, legislative, and juridical principles.

The impossibility of the gift that sublates the friend/enemy dichotomy is of a more robust transcendence. Overcoming the nation-state ontology in the interests of justice for a cosmopolitan citizenry is a matter of calculative planning within the socio-political domain. Responding to the impossibility of the gift in overcoming the 
friend/enemy dichotomy is a matter of hoping rather than planning - hoping as a feature of the ethico-religious dimension rather than calculative planning . To be sure, there is an orientation to the future in both cases, fueled by a dissatisfaction with the present - the present injustices and the present hatred for one's enemies. However, the mark of hope for the impossible beckons us beyond the socio-political sphere of existence to the ethico-religious dimension.

This move to the landscape of the religious, however, is not to be confused with the embrace of an institutionalized religion, with its exclusionary dogmas and doctrines. Paul Tillich already called our attention to this important difference in his distinction between "the religious" as a state of ultimate concern on the vertical dimension and "religion" as an institutional configuration of preliminary concern on the horizontal dimension (Tillirich, 1976). This distinction also appears to be at issue in Derrida's paradoxically articulated hope for a "religion without religion", messianicity without messianism-a messianicity that provides the opening to the future as the time of promise in which all distributive justice is crowned with the infinite disproportion of the gift without expectation of return (Derrida, 1998). And this is clearly the message of Kierkegaard in his Works of Love, from which we learn that the unconditional love of neighbor, which binds together a working or acting with a hoping or anticipating, extends also to our enemies for they too share the space of our neighborhood.

It is this message of the gift as unconditional love, always on the horizon and edge of our finite capabilities, that provides the source, content, and measure of our fitting response to the occurrence of evil. And if we continue to talk about the Deity in our preoccupation with the problem of evil, as we are wont to do-whether it be natural or moral evil-let us search for the Deity not in the causal conditions within the shifting of fault lines below the surface of the earth or in the inexplicable motivations to commit genocide, but rather in the call to a fitting response to the occurrences of evil in the world of nature and the travail of human history. God is in the responses to human misery, not in the ineluctable causes of human misery.

\section{References}

Wilshire, B. (2005). Get 'em all: genocide, terrorism, righteous communities (p. xiv). New York: Lexington Books.

Huntington, S. (1996). The clash of civilizations and the remaking of world order. New York: Simon $\&$ Schuster.

Habermas, J. (2001). The postnational constellation: political essays (M. pensky, trans.). Cambridge: The MIT Press.

Derrida, J. (1997). The politics of friendship (pp. 285-286). (G. Collins, Trans.). New York: Verso Press.

Kierkegaard, S. (1995). Works of love (pp. 67-68). (H. V. Hong \& E. H. Hong, Trans.). Princeton: Princeton University Press.

Tillich, P. (1976). "The lost dimension in religion." In W. B. Williamson, (Ed.), Decisions in the Philosophy of Religion (pp. 41-47). Columbus: Charles E. Merrill Publishing Company.

Derrida, J. (1998). "Faith and knowledge.” In J. Derrida \& G. Vattimo (Eds.), Religion (p. 17). Stanford: Stanford University Press. 